\title{
Creating an Intelligent Organisation as a Source of Competitive Advantages: Conditions and Dilemmas
}

\begin{abstract}
The purpose of this research is to identify the essence and features that allow for the identification of intelligent organisations and an assessment of their maturity, taking their competitive advantages into account. In addition, it aims at formulating recommendations on how to study intelligent organisations while considering competitive advantages and monitored changes in this area. A hypothesis is formed that the intelligent organisation is a source of competitive advantage for companies. These advantages are not permanent, though. The article is based on a critical review of national and foreign literature, as well as experience resulting from direct involvement and observations while participating in research focused on intelligent organisations. The research was a part of the Żagle Biznesu (Sails of Business) competition organised by the SGH Warsaw School of Economics in 2018 and 2019. According to the author, an intelligent organisation is one where decision-making is based on collecting, analysing, interpreting, sharing and storing valuable data and information, which can be used at the right time to solve problems and generate the competitive advantage of a company. The type of leadership and emotional intelligence of key people involved have a great impact on the development opportunities of companies creating intelligent organisations. In small companies, apart from a strong dependence on the type of leadership and focusing on a particular type of innovation, there is a lack of development strategy. Poor awareness of the need for development, as well as vulnerability to internal and external shocks (volatility), causes instability in previously achieved levels of intelligence. Small companies in a type of intelligent organisation can compete in the operational sphere, based on such factors as technology, quick response, good timing and better dealing with individual customers. At the same time, small companies can strengthen their competitive advantages related to costs and quality through dedicated operating systems in a way which is typical of large companies. Although these advantages are not permanent, some of them may be duplicated and modified.
\end{abstract}

Keywords: competitive advantage; intelligent company; intelligent organisation; operational management

Received: 3 July 2019

Accepted: 30 September 2019

\section{Suggested citation:}

Godlewska-Majkowska, H. (2019). Creating an intelligent organisation as a source of competitive advantages: conditions and dilemmas. Przedsiębiorczość - Edukacja [Entrepreneurship-Education], 15(2), 7-23. doi: 10.24917/20833296.152.1 
Introduction

The basis for the functioning of each enterprise is to find competitive advantages understood as those features that make a company better than others and create the opportunity to succeed against its competitors and maintain or increase its position on the market. This distinguishing feature could be related to quality, cost, technological character, and speed of response to changes in demand or customer service that may be better than somewhere else. Depending on the scale of the business, its type and business model, the distinguishing features of a company change over time and show volatility.

Creating a smart organisation is a chance to survive on the market or even strengthen those assets. Quick learning, adjusting organisational behaviour to market uncertainty and unconventional activities allow this type of organisation to benefit from information flowing from the market and the company itself. Nowadays, in the knowledge-based economy, the ability to seize the opportunity while using information better than other competitors makes companies more shock-resistant and capable of developing in accord with their own original vision.

The purpose of this research is to identify the essence and features that make it possible to identify intelligent organisations and assess their maturity considering their competitive advantages. Additionally, the goal is to formulate recommendations to serve as assistance while studying intelligent organisations in the context of competitive advantages and monitored changes in this area. The hypothesis states that an intelligent organisation is a source of competitive advantages for enterprises. These advantages are not permanent, though.

The article is based on a critical review of national and foreign literature, as well as experiences resulting from direct involvement and observation while participating in research focused on intelligent organisations. The research was a part of the Żagle Biznesu (Sails of Business) competition organised at the SGH Warsaw School of Economics in 2018 and 2019.

\section{The essence and development factors of an intelligent organisation}

Becoming familiar with the concept of organisational intelligence (OI) seems to be a starting point to understand what intelligent organisations are, since it is a feature that distinguishes these organisations from others.

Organisational intelligence is defined in various ways. In the most traditional, OI collects, processes, interprets and communicates the information needed for decision-making (Wilensky, 1967). One of the key conditions for an organisation to achieve success is the ability to generate the right amount and quality of information, and the ability to use and sustain it in an intelligent manner (Mikuła, 2006: 62-63).

Organisational intelligence can also be understood as "the intellectual ability of the entire organisation, including the ability to find the right place in a difficult and changing environment using the appropriate organisation pattern, infrastructure, strategy and business model. It also includes knowledge management, organisational learning and the ability to implement best practices and knowledge management processes dynamically. OI may give meaning to complex situations and effective actions applied on the ground to events and signals in the environment" (Bratnicki, 2002). 
In the literature one can also find a definition combining the intelligence of an organisation with its ability to develop and strengthen appropriate knowledge strategically in order to achieve its goals successfully (Bartnicka, 2011). It can also be pointed out that intelligence in relation to business is understood as the process of collecting, analysing, and interpreting high-value data and information for use at the right time in the decision-making process (López-Robles et al., 2019).

The concept of organisational intelligence must be distinguished from the concept of the intelligent organisation. Intelligence is a feature that characterises an organisation, which means it either has it or not. By extension, an intelligent organisation is an organisation that is intelligent, though it can be a property developed to varying degrees and duration.

In the literature, this difference is often blurred because the properties of an intelligent organisation are defined in such a way that make it unique and consequently intelligent. In literature, there are many approaches to the definitions of an intelligent organisation and organisational intelligence. These are usually definitions containing descriptive characteristics indicating the attributes of organisations regarded as intelligent (see Dyduch, Bratnicki, 2016).

One traditional approach develops a concept that an intelligent organisation is one which has the ability to forget and abandon old organisational habits and routines (Christensen, 1997). An intelligent organisation can be combined with the intelligent learning systems of educated people; it takes advantage of complex information networks to adapt to the turbulent world (Yaghoubi et al., 2012).

This process would not be effective if it was not accompanied by all employees learning during everyday informal practice, and a formal system of workshops and training sessions. Therefore, intelligent organisations are associated with the knowledge-based economy. Consequently, knowledge transfer processes are basic, and knowledge is considered to be the most important endogenous production factor that determines the company's competitiveness.

An intelligent organisation is a learning organisation that takes advantage of better access to information. That is why it is worth quoting the definition that "an intelligent company is a flexible, adaptive and innovative enterprise that can cope with high complexity, a huge amount of information, a high variety of expected services and perform its activities with high precision in order to achieve outstanding efficiency" (Thannhuber, 2005: 67).

The cybernetic approach is referenced by a list of intelligent organisation features formulated by Schwaninger (2006: 7), as follows:

- adaptation to changing situations, i.e. changes in the organisation due to external stimuli,

- exerting influence on one's environment and shaping it skilfully,

- if necessary, the ability to find a new environment ('a pitch') or to reconfigure itself in its own surroundings,

- a positive contribution to profitability and the development of a larger entirety in which an intelligent organisation is embedded ${ }^{1}$.

\footnotetext{
${ }^{1}$ In the literature there are many other approaches to this phenomenon. There are also various definitions and different sets of features that indicate intelligent organisations. However, they have been omitted because they are not particularly relevant for the objectives of this research.
} 
According to March, "an intelligent organisation is one that adopts procedures that work in the conditions of restrictions imposed by rare resources and competition" (after Grösser, Zeier, 1999: 129). This definition is complementary to the above, due to the inclusion of procedural efficiency and market restrictions.

Based on a combination of intelligent organisation features identified by Sydänmaanlakka (2002), Schwaninger (2006: 7), Garvin (1993), Grudzewski, Hejduk (2004: 135) and Łobejko (2009: 13), a certain set of features that characterize an intelligent organisation can be indicated:

- "having an enterprise development strategy that sets the framework for the functioning of an information strategy,

- the ability to generate, codify, store and transfer knowledge,

- active acquisition of knowledge from outside, including entering into cooperative relationships with other market participants (competitors, cooperators, recipients, customers) or business environment institutions,

- adaptability and easy application of new knowledge (innovation),

- hiring highly qualified specialists, so-called knowledge workers, and using their talents based on internal regulations within human capital management (human resources development plan, promotion rules, periodic assessments),

- the ability to learn at individual and group levels,

- creating the value of intellectual capital far exceeding the value of tangible assets

- products / services rich in knowledge and generating high added value,

- the use of modern methods and tools in company management" (Godlewska-Majkowska, 2013: 27).

There are many other approaches, among which the most important determinants of intelligent organisations include understanding the environment and conducting activities that lead to an adjustment in it, managing intangible resources, as well as designing organisation and using managerial skills appropriately (Dyduch, Bratnicki, 2016: 20).

All this could be synthetically presented in a flywheel formed by three components.

Defining an intelligent organisation, therefore, encounters many difficulties because in each definition there are various features. In addition, a diverse selection of key features causes ambiguity. In this research, thus, the author based her definition of the intelligence of an organisation on the one formulated by López-Robles, Otega-Olasoa, Porto-Gómez, Coboc (2019).

An intelligent organisation is one in which decision-making processes are based on the processes of collecting, analysing, interpreting, sharing and storing valuable data and information, used at the right time to solve problems and generate competitive advantages for the company. This definition will be used here as a basis for further discussion.

\section{The role of intellectual capital in creating an intelligent organisation}

The development of intelligent organisations can be the result of stimuli located both internally and externally, with Akgün, Byrne and Keskin (2007) pointing to three aspects of this process. The first one is accumulation, which means that the company aggregates the intelligence of the people available in the organisation. The second one is the transfer of individual intelligence to a group level, which means that the intelligence of individuals is transformed and codified as the knowledge and intelligence of the organisation. The third 
Figure 1. A flywheel of an intelligent organisation

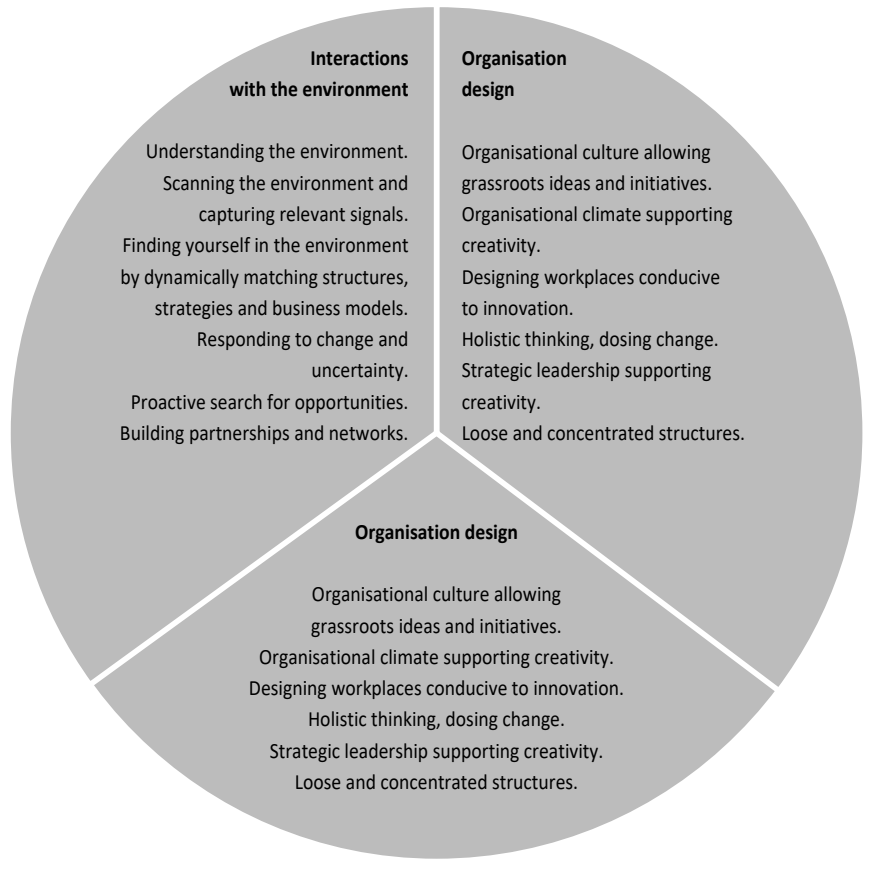

Source: Dyduch, Bratnicki (2016: 21)

one is distribution. At this point IO has become embedded in the structured thinking and action patterns in which members of the organisation interact and get involved.

These three levels are associated with elements of intellectual capital: structural and organisational capital, human capital as well as structural and relational capital; see Figure 2 (Hofman-Bang, Martin, 2005; Kasiewicz, Rogowski, 2008).

In a small company human capital is particularly important, especially the management with its managerial skills, type of leadership and the ability to cooperate complementary human experience. In addition, those employees who bring knowledge and general competences, who are engaged in the development of structural and organisational capital, are valuable to the organisation.

Considering the existence of different types of personalities and roles in the company, it can be concluded that leaders with a unique leadership style, which is difficult to copy, are significant for establishing an intelligent organisation. These are leaders who set the key values for the organisation. Besides identifying with key values, they trigger the desire to share experience, knowledge and creative ideas initiated by information and ability to process it. The intelligence of people who are key to the company turns into the intelligence of the organisation.

Structural capital is also important for the intelligent organisation. Consequently, it refers to the organisational structure and systems that support the multiplication of human capital, even if employees leave the organisation (Xiao, Cao, Zhang, 2018).

In this context, the organisational structure of the enterprise supporting effective knowledge management is also important. Horizontal structures based on a flexible 


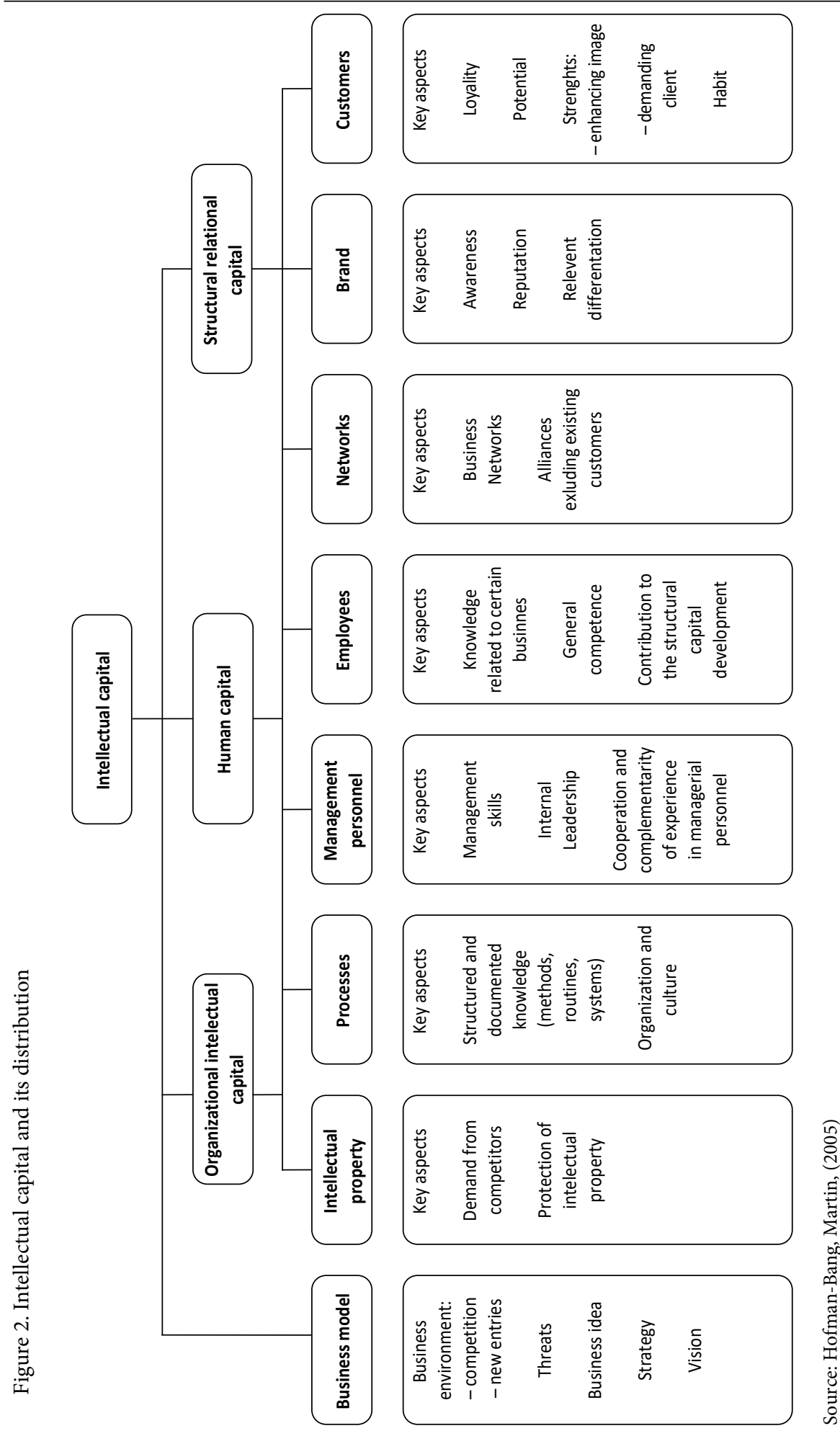


approach to the organisation of teamwork make it possible to select and develop talents, assign tasks to specific employees based on the self-organisation in teamwork, and at the same time encourage the synergy of team members' activities. On the other hand, vertical structures can work for tasks where flexibility is limited due to legal requirements and high-quality standards that require detailed documentation.

It may turn out that a horizontal structure does not work in a particular situation, but the vertical structure does. It can happen that both structures are justified in accordance with the requirements of specific projects, so-called "ambidextrous" organisation (Zakrzewska-Bielawska, 2016). Companies that use such an organisation have separate organisational cells which are focused on seeking innovation within traditional operating units. The coexistence of different models of work organisation also meets the need to adapt work styles arising from cultural differences from internationalisation or the multi-generational nature of teams. As a result of this approach, both types can use different processes and have different organisational structures and cultures.

This type of behaviour can be seen in banks which separate new organisational units for the purposes of developing a new offer addressed to younger generations of customers. This type of project may be the reason for an emerging independent entity, created from the beginning as an intelligent organisation for the needs of a regular corporate client. However, this behaviour is more typical of large organisations rather than small businesses.

Intelligent organisations can, however, be created inside large companies for planning or designing work, as evidenced by developing a Goodi application at Bank Millennium. Solutions related to mobile banking have also been created in intelligent organisations emerging in large companies for the needs of specific tasks and projects. Hence unique solutions, which meet new market needs, were developed, e.g. BLIK at PKO BP. There are also projects that promote an idea of 'employee volunteering' in a typical way for intelligent organisations, e.g. at Santander Bank, where intelligent teams of employees support valuable social initiatives.Large companies can also be a source of inspiration for creating intelligent organisations in their environment, not only through outsourcing and offshoring, but also through initiatives in the area of social responsibility. The existence of 'business angels' and companies based on venture capital are contributing factors too. Franchise options are conducive to the spread of intelligent solutions, for example by sharing marketing, organisational or pro-social innovations. It depends on the companies involved in this type of activity, how they will use the intellectual capital provided by an external entity, and to what extent they develop their own solutions or, in a negative scenario, waste their chances.

Therefore, there are many ways to develop an intelligent organisation based both on the internal potential of companies and the impact of stronger business partners, as well as public partners creating various types of support for start-ups and small businesses.

The intelligent organisation can also be a virtual creation, with a structure difficult to identify because new entities can join and existing ones can leave. The structure may also require significant virtualisation of work in open project systems which arises from the growing role of corporate social responsibility (CSR) and the formation of structures for volunteering. It is increasingly popular to create shared database resources and Open Source software on a global scale as an indispensable condition for selecting effectively functioning groups. 
Another important element is the organisational culture co-created by a leader and other key personnel. Since creating an atmosphere of openness and cooperation is crucial here it opens up opportunities to increase an employee's creativity. Additionally, investing in training of employees to improve their qualifications socialises the decision-making process.

The importance of the above factors is confirmed by the research of Wong and Aspinwall (2005: 64-82) based on an analysis of British companies. This research indicates the key role of leadership, organisational structure, human resource management and culture. Regarding IT technologies the authors only treat them as a necessary tool in information management. Nevertheless, it is an important tool as there is a growing need for selecting and efficiently processing information in the business decision-making process. It is even more significant considering the growing globalisation of operations which newly established companies are often involved in. Besides, they are focused on the internationalisation of the offer and operations as global companies.

In the light of these results, it is worth distinguishing two types of mechanism leading to creating intelligent organisations, i.e. endogenous and exogenous. The first one proceeds from the autonomy of decisions of the company's leaders who decide the organisation's development because decision-making is their competence. However, the development of an intelligent organisation may also come from the decisions of an external entity that comes to a decision for example as a key recipient or supplier of products or services. It could also be another company or an individual controlling the company as a result of corporate governance. Franchise-based business models would make a great example.

Based on the experience, patents or codified knowledge of a stronger partner, a company can develop the features of an intelligent organisation. However, there is a risk that the adopted solution will not prove beneficial in a particular company due to technological, personnel, legal or other threats.

As already mentioned, an intelligent organisation is based on the rapid assimilation of information and building knowledge from it, circulating it inside the company and among authorised stakeholders. The condition for the effectiveness of this process is to trigger cognitive processes among employees and owners. Consequently, discussing to what extent the intelligent organisation is influenced by human emotions and interpersonal relationships seems to be worthwhile.

\section{Emotional factors in creating intelligent organisations}

If intelligence in relation to a person is understood in the context of skills in the field of abstract thinking, learning, perceiving dependencies and relations between different facts, and drawing different conclusions on this basis, then this concept can also be approached at the organisational level. It is possible to relate the individual intelligence of key personnel, especially the owner-founder, to the social entities that are created, including the company and its organisation (Adamik, 2018: 83).

State of mind affects the level of human intelligence, hence emotional intelligence is distinguished. So, the question is if it is possible that the emotional intelligence of an organisation will affect the level of development and efficiency of the intelligent organisation.

The answer to this question is affirmative if we take into account the overwhelming impact of the emotional condition of key people in the company on their business 
Figure 3. Health of organisations and types of relationships

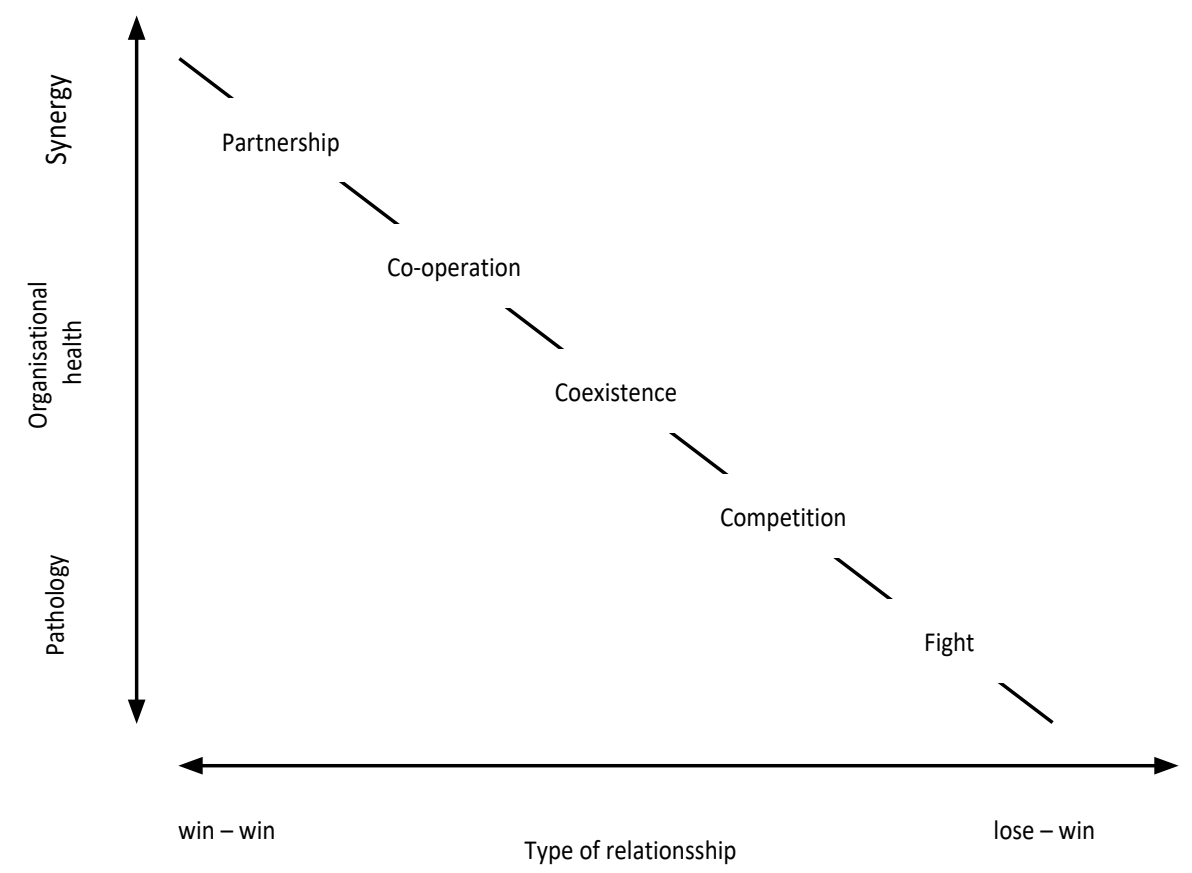

Source: Elsner (2014: 199)

decisions, or the impact of the mental state of leaders on relations in the company. Namely, we can understand organisational emotional intelligence as a combination of the aggregated level of the individual emotional intelligence of employees and the use of emotionally intelligent procedures, norms and behaviours in the whole organisation. Preliminary evidence suggests that organisational emotional intelligence is positively associated with organisational performance and employee health. Organisations may be able to increase this intelligence by gathering individual emotional intelligence among their employees and using emotionally intelligent procedures (Menges, 2012: 355-373).

Interactions between people in a company have their own temporal context and affect the self-improvement of an intelligent organisation, as pointed out by March (2009). The author notes that each intelligence rating depends on the chosen time and place. It can have a seriously negative impact on the learning process of the organisation because reaching for experience is fraught with the subjectivity of the recalled past. There is also a conflict of desires, interests and attitudes of employees.

That is why it is worth quoting various types of relationships between an organisation and its health, expressed in the following dimensions: flexibility, rejuvenation, enforcement, complementarity and complementation (Bratnicki, Kulikowska-Pawlak, Graca, 2014); see Figure 3.

Relational capital enables fast transfer and exchange of knowledge, which in the case of modern knowledge-based organisations is an important pillar of its functioning and development. It can determine innovation and competitiveness in the current market 
which is changing so rapidly. Therefore, an intelligent organisation should be healthy, and the interpersonal relationships that support information and knowledge sharing ought to be based on cooperation and collaboration instead of conflict and competition. The more creative the relationship and the healthier nature of an organisation, the less disturbed the emotional intelligence. Access to information can trigger different reactions depending on the propensity to take risk or, on the contrary, the propensity to avoid it and focus on secure solutions. Therefore, susceptibility to quick reactions resulting from the unpredictability of business conditions is strongly associated with leaders and the type of emotional intelligence of both leaders and the entire organisation.

In small enterprises, owners often play the role of a leader creating a vision of the IO goal and ways to achieve it combining leadership with management. Leadership is not based on a formally higher position in the company structure, but it is closely related in small and especially in micro-businesses.

Therefore, it often happens that the owner of the company has a vision of the company's development, but it is in an unrecorded form and thus inaccessible to others. The owner can often change it because of numerous threats to the existence, e.g. due to lack of experience, a poor bargaining position or the work resources for the company's development are too small or relatively inadequate.

The owner's intelligence can have an overwhelming impact on the intelligence of the entire organisation and IO itself. Properly, the intelligent organisation of a company may undergo negative changes due to key employee turnover or personal problems of the owner. Appropriately, intelligent organisations are often associated with a specific project or product and are not a feature of the entire company. As a result, it is worth viewing them through particular types of innovation concerning product, process, organisation, pro-social issue and marketing.

In small companies, apart from the strong dependence on the type of leadership and focus on a particular type of innovation, there is a lack of development strategy and awareness. Additionally, susceptibility to internal and external shocks can cause instability in the level of intelligent organisation development previously achieved. This conclusion is indicated by the results of research on intelligent organisations in small companies (Godlewska-Majkowska, 2013). Here innovative solutions are often the result of the work of a relatively small group of employees or a stakeholder supporting the development. The small scale of operations creates a risk of copying the solutions by larger and stronger market participants. If several key people leave the company, it can drastically reduce the potential of the intelligent organisation because of the inevitable reduction of intellectual capital.

\section{Dilemmas of measuring the intelligent organisation of companies}

There are several important dilemmas in determining the level of IO development. The first is related to what should be measurement: the intelligence of an organisation or the level of maturity of an intelligent organisation.

Since it is known that the concept of an intelligent organisation is a subject of discussion, and researchers accept various sets of features as necessary to define an organisation as an intelligent one, the question arises which features constitute the basis for measuring the level of development of intelligent organisation. Is there a kind of an IQ indicator for companies? 
Assuming that an intelligent organisation is related to the intelligence of its employees, we can examine the IQ of employees and assume that the higher the intelligence resources of those working in it, the more developed the intelligent organisation is. One can also try to estimate the value of intangible assets, indicating the value of knowledge as a commercial product.

However, such approaches are very difficult to apply because there is no way of checking whether employees and owners are involved in work in a way that allows the use of the potential of intelligence, and whether their intelligence fluctuates according to the occurrence of threats, or changes in relations within the company.

The second dilemma is the selection of criteria for assessing the level of development of an intelligent organisation. Depending on the selection of criteria, the results for assessing the maturity of an intelligent organisation will differ.

If it is assumed that if the more features indicating its occurrence, the more developed an intelligent organisation is, then it is possible to measure this type of organisation. However, it should be remembered that the development potential of an intelligent organisation is being assessed because this approach does not apply to the effects of this intelligence, for instance to the competitiveness of companies. In the study carried out by a team led by Godlewska-Majkowska in 2013, small companies in the Mazovia region were looking for the leading features of identified intelligent organisations.

These were features such as the ability to generate, codify, store and transfer knowledge:

- the ability to learn at individual and group levels,

- adaptability and ease of application of new knowledge,

- active acquisition of knowledge from outside, including entering into cooperative relationships,

- employing highly qualified specialists and using their talents,

- possessing a formalised business development strategy,

- having legal regulations regarding human capital management (i.e. personnel development plans, promotion rules or periodic evaluation) (Godlewska-Majkowska, 2013; Ginter, Kałuża, 2013).

Another attempt to identify intelligent organisations and assess their maturity is the work accompanying the Żagle Biznesu (Sails of Business) competition at the SGH Warsaw School of Economics. This competition aims to identify intelligent organisations among companies founded by the SGH graduates or students. In 2018 three companies with the features of intelligent organisations were identified and awarded. It is worth emphasising that these companies represented different scale of operation, different types of activity, different competitive advantages and different business models. What they had in common was the use of modern IT systems, investment in human capital and the ability to develop quickly. They were distinguished by the creative attitudes of employees and management staff.

They were selected based on criteria such as:

- ability to generate, codify, store and transfer knowledge,

- active acquisition of knowledge from outside, including entering into cooperative relationships,

- adaptability and ease of application of new knowledge (innovation),

- employing highly qualified specialists, so-called knowledge workers and using their talents, 
- ability to learn at individual and group levels,

- the value of intellectual capital far exceeding the value of material capital,

- producing knowledge-rich products or services generating high added value,

- possessing an information strategy or including information issues in the company's strategy,

- having internal regulations regarding human capital management (human resources development plan, promotion rules, periodic assessments),

- using modern methods and tools in company management (e.g. Business Intelligence, TQM, balanced scorecard, ISO quality systems, HACCP system),

- establishing permanent formalised relationships with other market participants (competitors, co-operators, recipients, customers) or business environment institutions,

- using knowledge management systems in the organisation,

- other practices proving that the company intentionally manages the process of creating and acquiring knowledge in order to gain a competitive advantage (source: archival materials of the SGH Warsaw School of Economics).

The following criteria were used to check the effects of intelligent behaviour within the candidate companies:

- innovation of good practice,

- regularity of activities implemented as part of good practice,

- the appropriacy of practices in relation to running the business,

- the company's current competitive position resulting from the application of good practice,

- the company's growth potential as a result of good practice ${ }^{2}$.

That is why it is worth adjusting the criteria to a type of company in terms of its innovativeness regarding product, technology, organisation and corporate social responsibility.

Another dilemma is taking into account the size of the company and the profile of its activity while measuring intelligent organisation. A different set of features should be considered for small companies who, for example, will need less complex information and knowledge-management solutions in the early stages of the life cycle. On the other hand, there are large enterprises where multiple operational, financial and marketing processes necessitate the implementation of very extensive improvement activities for information and knowledge management in modern databases (e.g. CRM).

Measuring the maturity of an intelligent organisation also requires taking into account the type of business activity. There are particularly important elements, such as the life cycle length of the dominant product or services provided by the company, the geographical range of sales markets and how it increases the innovation offer. It is essential to know whether the organisation bases its business model on original innovations, or focuses on the successful modification, diversification or personalisation of already existing goods and services on the market.

Therefore, in the study of intelligent organisations within the second Żagle Biznesu (Sails of Business) competition at the SGH Warsaw School of Economics in 2019, having stated that analysed organisations are highly diverse, especially in terms of the size and

${ }^{2}$ Based on competition documentation and the author's own materials as the chairwoman of the Jury of the Żagle Biznesu (Sails of Business) Competition held at the SGH Warsaw School of Economics in 2018. 
business model advancement, it was decided to distinguish several categories of intelligent behaviours according to types of innovation, such as product, organisational, technological, marketing and CSR innovations. Consequently, strict criteria were applied to make an assessment of each category. Regardless of the specifics of innovation, the subject of the assessment was the competitive advantage resulting from the intelligent organisation existing in the company.

\section{Intelligent organisation and the company's competitive advantages}

An intelligent organisation of a company translates into competitive advantages and competitiveness. The question arises of what types of competitive advantage are directly or indirectly related to an intelligent organisation. This is a very broad issue due to many potential competitive advantages. To focus on the most important, a particular method of analysis will be used, relevant to those advantages arising in the operational sphere.

Assuming that competitiveness is the ability to be better than others, then the approach proposed by Waters (2002) is a good starting point. In his view, the basic competitive advantages are low prices, high product quality, supplying products when demand occurs, keeping waiting periods for products limited to a minimum, products being tailored to the needs of customers, adaptability to different levels of demand, a high degree of product sophistication, and customer care. All these operational advantages can be achieved by rationalising operational processes in the company related to the sphere of production management and logistics.

An intelligent organisation gives the opportunity to enhance all of the indicated competitive advantages. Therefore, Table 1 presents an example of operational strategies highlighted by Waters (2002), links between intelligent organisations, and competitive advantages considered through the key elements of the company and the consequences for the operating system.

Table 1. Operational strategies and their implications for the operating system of companies with the features of intelligent organisations

\begin{tabular}{|l|l|l|l|}
\hline $\begin{array}{c}\text { Key } \\
\text { element }\end{array}$ & $\begin{array}{l}\text { Competitive } \\
\text { Advantage }\end{array}$ & \multicolumn{1}{|c|}{$\begin{array}{c}\text { Operations system } \\
\text { profile }\end{array}$} & $\begin{array}{l}\text { Feature of intelligent organisation / } \\
\text { Impact of intelligent organisation }\end{array}$ \\
\hline Costs & Low prices & $\begin{array}{l}\text { Large scale production, } \\
\text { automation, high } \\
\text { productivity, standard } \\
\text { products, low fixed costs }\end{array}$ & $\begin{array}{l}\text { Automation requires the use of mod- } \\
\text { ern solutions, e.g. technological inno- } \\
\text { vations, like flexible production cells. } \\
\text { It brings benefits in the form } \\
\text { of reduced costs of labour in difficult } \\
\text { conditions or requiring high precision }\end{array}$ \\
\hline Quality & $\begin{array}{l}\text { High product } \\
\text { quality }\end{array}$ & $\begin{array}{l}\text { Reliable process, TQM, } \\
\text { low product and oper- } \\
\text { ational variability, high } \\
\text { quality of materials }\end{array}$ & $\begin{array}{l}\text { Dedicated information systems based } \\
\text { on the internet foster maintaining } \\
\text { the reliability of the quality control } \\
\text { and management system }\end{array}$ \\
\hline Timing & $\begin{array}{l}\text { Delivering } \\
\text { products when } \\
\text { the need arises }\end{array}$ & $\begin{array}{l}\text { Delivering products } \\
\text { when the need arises }\end{array}$ & $\begin{array}{l}\text { Creating dedicated systems based on } \\
\text { the latest technologies, e.g. CRM, ERP, } \\
\text { very promising for businesses based } \\
\text { on shared economy, strengthening } \\
\text { the decision-making process }\end{array}$ \\
\hline
\end{tabular}




\begin{tabular}{|c|c|c|c|}
\hline $\begin{array}{l}\text { Speed } \\
\text { of reaction }\end{array}$ & $\begin{array}{l}\text { The waiting } \\
\text { period for } \\
\text { products } \\
\text { limited to } \\
\text { a minimum }\end{array}$ & $\begin{array}{l}\text { Appropriate processing } \\
\text { capacity, operating sys- } \\
\text { tem capable of quick re- } \\
\text { sponse, developed work } \\
\text { planning system, close } \\
\text { customer relationships }\end{array}$ & $\begin{array}{l}\text { Systems accelerating the inflow of } \\
\text { information and their processing in- } \\
\text { crease the reactivity of the operating } \\
\text { system, assist planning work better } \\
\text { and acquire employees who are } \\
\text { necessary at a particular time, modify } \\
\text { the work organisation and improve } \\
\text { customer relationships }\end{array}$ \\
\hline $\begin{array}{l}\text { Product } \\
\text { flexibility }\end{array}$ & $\begin{array}{l}\text { Products } \\
\text { tailored to the } \\
\text { needs of cus- } \\
\text { tomers }\end{array}$ & $\begin{array}{l}\text { An extensive operating } \\
\text { system capable of quick } \\
\text { response, qualified em- } \\
\text { ployees, the ability to } \\
\text { introduce changes in the } \\
\text { process quickly, custom- } \\
\text { er involvement }\end{array}$ & $\begin{array}{l}\text { The operating system based on intelli- } \\
\text { gent solutions which make it possible } \\
\text { to use the potential of qualified know- } \\
\text { ledge workers and personalise the offer }\end{array}$ \\
\hline $\begin{array}{l}\text { Flexibility } \\
\text { against } \\
\text { changes in } \\
\text { demand }\end{array}$ & $\begin{array}{l}\text { Adaptability to } \\
\text { different levels } \\
\text { of demand }\end{array}$ & $\begin{array}{l}\text { Flexibility of production } \\
\text { capacities, operating } \\
\text { system capable of quick } \\
\text { response, developed } \\
\text { work planning system, } \\
\text { short production cycle } \\
\end{array}$ & $\begin{array}{l}\text { IO can make production capacities } \\
\text { more flexible owing to the speed } \\
\text { of operation on the global supply } \\
\text { markets }\end{array}$ \\
\hline Technology & $\begin{array}{l}\text { High level of } \\
\text { product so- } \\
\text { phistication }\end{array}$ & $\begin{array}{l}\text { Investments in R\&D, } \\
\text { ability to constantly in- } \\
\text { novate, use of new ideas }\end{array}$ & $\begin{array}{l}\text { The organisation and operating sys- } \\
\text { tem are based on modern technologies } \\
\text { that use a constant flow of information } \\
\text { from the inside and from the competi- } \\
\text { tive IO environment }\end{array}$ \\
\hline $\begin{array}{l}\text { Customer } \\
\text { service }\end{array}$ & Customer care & $\begin{array}{l}\text { Close relations with the } \\
\text { customer, obtaining } \\
\text { information from the } \\
\text { customer, flexibility, } \\
\text { openness to suggestions }\end{array}$ & $\begin{array}{l}\text { Modern dedicated information sys- } \\
\text { tems and relational capital are condu- } \\
\text { cive to effective customer relationship } \\
\text { management and after-sales care } \\
\text { as well as offer design. It is facilitated } \\
\text { by an automated customer service } \\
\text { system at the after-sales stage as well. }\end{array}$ \\
\hline
\end{tabular}

Source: based on Waters (2002)

In the light of the presented relationships between intelligent organisations and competitive advantages, it can be stated that all basic competitive advantages can be enhanced in a company due to its intelligent organisation. However, these competitive advantages refer to technology (technological innovations), speed of response owing to information management with the support of modern technologies: competitive advantages based on timing, speed of response and customer service.

These competitive advantages are based on flexibility and maintaining direct customer service where the customers are treated individually. Intelligent organisations, therefore, strengthen the specific positive features of small businesses, so they can compete with larger, less flexible companies focused on large-scale operations and cost optimisation by reducing fixed costs per product unit.

\section{Conclusion}

There is no unambiguous universally accepted definition of an intelligent organisation, although it is known that it exists. According to the author, it should be considered as one 
in which decision-making processes are based on the processes of collecting, analysing, interpreting, sharing and collecting valuable data and information, which can be used at the right time to solve problems and generate competitive advantages for a company. This feature distinguishes intelligent organisations from other types.

The properties which an intelligent organisation has and the way it can be measured depends on the stage of its development, its specific activity and the dominant type of innovation concerning product, technology, organisation, marketing and corporate social responsibility.

There are several important dilemmas in determining the level of intelligent organisation development. The first one is related to measurement whether it is the intelligence of an organisation or the level of maturity of the intelligent organisation should be measured.

When measuring company intelligence, there is a problem in assessing its actual use, and how it is modified by emotional intelligence. While measuring the maturity of an intelligent organisation, the selection of criteria for assessing the level of intelligent organisation development becomes a challenge. These results will differ depending on the selection of criteria, therefore it is worth adjusting them to the type of the company in terms of its type of innovation for product, technology, organisation and corporate social responsibility.

The second dilemma is the issue of measuring an intelligent organisation depending on the size of the enterprise and its business profile. Different sets of features should be considered for small enterprises, which, for example, will need less complex information and knowledge management solutions in the early stages of the life cycle. Consequently, there are other features for large enterprises where multiple operational, financial and marketing processes necessitate the implementation of very extensive activities streamlining information and knowledge management in modern databases (e.g. CRM). Measuring the maturity of an intelligent organisation is also complicated by the type of activity, especially the life cycle length of the dominant product or service provided by the enterprise, geographical coverage and the character of the offer.

Distinguished by intelligent organisation, small companies take advantage to strengthen their competitive advantages, which significantly improve operational processes in terms of speed of response, optimise the use of competitive potential, especially within intellectual capital.

The type of leadership - founders or business owners - has a great impact on the development opportunities of companies based on intelligent organisations. Their perception of the business model and development strategy influence decisions that trigger the growth of the company's intellectual capital. In addition, their decisions anticipate their competitors.

It may happen that intelligent organisations do not achieve lasting competitive advantages, especially in crisis conditions in which the emotional intelligence of key personnel affects the entire organisation. In small businesses the departure of several key people from the company can drastically reduce the potential of IO, inevitably reducing the intellectual capital.

Not only can intelligent organisations develop on the basis of internal stimuli, but also from their environment. Business relationships with franchisors, 'business angels' and big companies that incorporate small intelligent organisations are particularly important. 
In small companies, apart from a strong dependence on the type of leadership and focusing on a particular type of innovation, there is a lack of development strategy or weak awareness in the company, as well as susceptibility to internal and external shocks, which causes the instability of previously achieved levels of intelligence. There is a considerable risk if copying innovative solutions by larger and stronger market participants.

Small businesses with the features of intelligent organisations can compete in the operational sphere by better organisation of production and logistics, basing them on elements such as technology, speed of response, timing and customer relations.

At the same time, existing dedicated operating systems can strengthen the competitive advantages which are typical of large companies and are related to costs and quality. However, these advantages cannot be taken for granted and must be under continuous monitoring assessment leading to the improvement of processes, changes in the business model and even business strategy, if necessary. In conclusion, IO is a source of competitive advantage for small companies. These advantages are not permanent however and some of them could be copied or modified.

\section{References}

Adamik, A. (2018). Inteligencja organizacji w erze IR 4.0. Studia i Prace Kolegium Zarządzania i Finansów, 161, 81-97.

Akgün, A.E., Byrne, J., Keskin, H. (2007). Organizational intelligence: a structuration view. Journal of Organizational Change Management, 20(3), 272-289.

Beyer, K. (2012). Współczesna organizacja-organizacja oparta na wiedzy. Zeszyty Naukowe Uniwersytetu Szczecińskiego, 736, 9-25.

Bartnicka, K. (2011). Rola przywództwa w stymulowaniu twórczości w organizacjach. Organizacja $i$ Kierowanie, 4(147), 129-141.

Bratnicki, M., Kulikowska-Pawlak, M., Graca, K. (2014). Zdrowie organizacji jako koncepcja doskonałości. Prace Naukowe Uniwersytetu Ekonomicznego we Wrocławiu, 357, 9-16.

Bratnicki, M. (2002). Przedsiębiorczość i przedsiębiorcy współczesnych organizacji. Katowice: Wydawnictwo Akademii Ekonomicznej w Katowicach.

Christensen, C.M. (1997). Making strategy: Learning by doing. Harvard Business Review, 4, 141-156.

Elsner, D. (red.). (2014). Sieci wspótpracy i samokształcenia. Warszawa: Wolters Kluwer.

Dyduch, W., Bratnicki M. (2016). Charakterystyka inteligentnej organizacji. Studia i Prace Kolegium Zarzadzania i Finansów, 149, 9-24.

Garvin, D. (1993). Building a learning organization. Harvard Business Review, August, 78-91.

Ginter, A., Kałuża, H. (2013). Inteligentna organizacja jako źródło sukcesu organizacji na wybranych przykładach. Zeszyty Naukowe UPH w Siedlcach. Administracja i Zarzadzanie, 97, 113-123.

Godlewska-Majkowska, H. (red.). (2013). Inteligentne organizacje - dystrybucja wiedzy, kompetencje pracowników, miejsce na rynku. Warszawa: ZPWiM.

Grösser, S.N., Zeier R. (ed.). (2012). Systemic Management for Intelligent Organizations Concepts, Models-Based Approache and Applications. Berlin Heidelberg: Springer-Verlag.

Grudzewski, W., Hejduk, I. (2004). Zarządzanie wiedza w przedsiębiorstwach. Warszawa: Wydawnictwo Difin.

Hofman-Bang, P., Martin, H. (2005). IC Rating na tle innych metod oceny kapitału intelektualnego. E-mentor, październik.

Kasiewicz, S., Rogowski, W. (2008). Kapitał intelektualny. Spojrzenie w perspektywy interesariuszy. Warszawa: Wolters Kluwer. 
López-Robles, J.R., Otegi-Olaso, J.R., Porto-Gómez, I., Cobo, M.J. (2019). 30 years of intelligence models in management and business: A bibliometric review. International Journal of Information Management, 48, 22-38.

Łobejko, S. (2009). Trendy rozwojowe inteligentnych organizacji w globalnej gospodarce. Ekspertyza współfinansowana przez Unię Europejską w ramach Europejskiego Funduszu Społecznego. Warszawa.

Menges, J.I. (2012). Organizational Emotional Intelligence: Theoretical Foundations and Practical Implications. W: N.M. Ashkanasy, Ch.E.J. Härtel, W.J. Zerbe (ed.). Experiencing and Managing Emotions in the Workplace (Research on Emotion in Organizations), Vol. 8, Emerald Group Publishing Limited, 355-373.

Piwoni-Krzeszowska, E. (2013). Logiki kreowania wartości relacji przedsiębiorstwa z rynkowymi interesariuszami. Organizacja i Kierowanie, 2, 85-97.

Schwaninger, M. (2006). Intelligent organizations. Powerful models for systemic management. Berlin, Heidelberg: New York Springer.

Sydänmaanlakka, P. (2002). An Intelligent Organization: Integrating Performance, Competence and Knowledge Management. Oxford: Capstone Publishing Limited.

Thannhuber M.J. (2005). The intelligent enterprise: theoretical concepts and practical implications. New York: Physica-Verlag, A Springer Company.

Mikuła, B. (2006). Organizacje oparte na wiedzy [Knowledge-based organisations]. Kraków: Wydawnictwo $\mathrm{AE}$.

Waters, D. (2002). Operations management: producing goods and services. Financial Times. Prentice Hall.

Wierzbiński, B. (2019). Zasoby niematerialne w procesie tworzenia przewag konkurencyjnych małych i średnich przedsiębiorstw przygranicznych. Prace Naukowe Wydziału Ekonomii Uniwersytetu Rzeszowskiego. Monografie i Opracowania, 25.

Wilensky, H.L. (1967). Organizational Intelligence. London: Basic Books.

Wong, K., Aspinwall A. (2005). An empirical study of the important factors for knowledge-management adoption in the SME sector. Journal of Knowledge Management, 9(3), 64-82.

Yaghoubi, N., Behtarinejad, E., Gholami, S. and Armesh, H. (2012). The relationship between strategic process of knowledge management and organizational intelligence. African Journal of Business Management, 6(7), 2626-2633.

Xiao, J., Cao, L., Zhang, L. (2018). OIQ or OEQ, which matters more: evidence from China. Journal of Organizational Change Management, 31(2), 252-267.

Zakrzewska-Bielawska, A. (2016). Ambidextrous organization jako przykład przedsiębiorstwa inteligentnego. Studia i Prace Kolegium Zarządzania i Finansów. Szkoła Główna Handlowa, 148, 161-174.

Hanna Godlewska-Majkowska, professor, Collegium of Business Administration, Vice Rector for Outreach, Warsaw School of Economics. Scientific interests: location of enterprises, regional entrepreneurship investment attractiveness and competitiveness of regions, territorial marketing, Small and Medium Enterprises (sources of success, threats, intelligent organizations), financial management of local government units.

ORCID: 0000-0003-3841-1596

\section{Address:}

Szkoła Główna Handlowa w Warszawie

Kolegium Nauk o Przedsiębiorstwie

al. Niepodległości 162

02-554 Warszawa, Poland

e-mail: hgodle@sgh.waw.pl 